\title{
Creationism and intelligent design
}

\author{
Michael J Reiss \\ UCL Institute of Education, 20 Bedford Way, London WC1H 0AL, UK \\ m.reiss@ucl.ac.uk
}

\begin{abstract}
Until recently, little attention has been paid in the school classroom to creationism and almost none to intelligent design. However, creationism and intelligent design appear to be on the increase and there are indications that there are more countries in which schools are becoming battlegrounds over them. I begin by examining whether creationism and intelligent design are controversial issues, drawing on Robert Dearden's epistemic criterion of the controversial and more recent responses to and defences of this. I then examine whether the notion of 'worldviews' in the context of creationism is a useful one by considering the film March of the Penguins. I conclude that the 'worldviews' perspective on creationism is useful for two reasons: first, it indicates the difficulty of using the criterion of reason to decide whether an issue is controversial or not; secondly, it suggests that standard ways of addressing the diversity of student views in a science classroom may be inadequate. I close by examining the implications of this view for teaching in science lessons and elsewhere, for example in religious education lessons and at primary level where subject divisions cannot be made in so clear-cut a manner.
\end{abstract}

\section{The importance of creationism and intelligent design for schools}

Creationism and intelligent design raise issues for education that are both conceptually interesting and practically important. These issues include how we arrive at reliable knowledge, what the aims of schooling are (or should be), and how schools should deal with controversial or sensitive issues. 
Creationism exists in a number of different versions but, depending on the country, from as few as $5 \%$ to over $50 \%$ of adults reject the theory of evolution. Instead, they believe that the Earth came into existence as described by a literal (fundamentalist) reading of the early parts of the Bible, the Qu'ran or other scriptures and that the most that evolution has done is to change species into related species (Miller et al., 2006; Reiss, 2011). For a creationist it is possible, for example, that the various species of squirrels had a common ancestor but this is not the case for the various species of squirrels, gazelles and cats - still less for monkeys and humans, for birds and reptiles or for the blue whale and the banana.

Allied to creationism is the theory of intelligent design. While many of those who advocate intelligent design have been involved in the creationism movement, to the extent that the US courts have argued that the country's First Amendment separation of religion and the State precludes its teaching in public schools (Moore, 2007), intelligent design can claim to be a theory that simply critiques evolutionary biology rather than advocating or requiring religious faith. Those who promote intelligent design typically, but not always, come from a conservative faith-based position. However, in their arguments, they make no reference to the scriptures or a deity but argue that the intricacy of what we see in the natural world, including at a sub-cellular level, provides strong evidence for the existence of an intelligence behind this (e.g., Behe, 1996; Dembski, 1998; Johnson, 1999). Natural selection, acting on its own from inorganic precursors, is held to be inadequate.

Until fairly recently, little attention has been paid in the school classroom or the philosophy of education literature to creationism and almost none to intelligent design. However, creationism and intelligent design appear to be on the increase, and there are indications that there are more countries in which schools are becoming battlegrounds for the issue. For example, while the USA has had several decades of legal battles about the place of creationism and (more recently) intelligent design in schools (Moore, 2007), school-based conflicts over these issues are becoming more frequent in a range of other countries (Graebsch \& Schiermeier, 2006; Blancke, Hjermitslev \& Kjærgaard, 2014). There was consternation in the UK science education community when, in December 2009, many secondary school and higher education libraries 
received a complimentary copy of the book by Stephen Meyer et al. titled Explore Evolution, which, in the words of its website, sets out:

to examine the scientific controversy about Darwin's theory, and in particular, the contemporary version of the theory known as neo-Darwinism. Whether you are a teacher, a student, or a parent, this book will help you understand what Darwin's theory of evolution is, why many scientists find it persuasive, and why other scientists question the theory or some key aspects of it. ${ }^{1}$

Such events have led to a growth in the educational literature examining creationism and/or intelligent design (Jones \& Reiss, 2007; Williams, 2008; Laats \& Siegel, 2016).

The school classroom, of course, is not the only place where creationism and intelligent might be addressed. There are the beginnings of a literature on the way that natural history and other museums present the issue of evolution (Bennett, 2004; Scott, 2007; Trollinger \& Trollinger, 2016) and many of us also learn about evolution, creationism and intelligent design through radio and TV programmes, by reading popular science books and by other means. Nevertheless, there is a particular need to address the issue of whether, and if so how, schools might address the issue of creationism, particularly for the age range of students for whom education is mandatory.

\section{Are creationism and intelligent design controversial issues?}

It may seem somewhat surprising to ask if creationism and intelligent design are controversial issues given the furore that regularly surrounds them in many countries in the courts, in the media and in schools but the answer is a useful one because there is a considerable literature on how controversial issues might be addressed in education. Much of the recent academic literature in education on controversial issues hinges on the work of Robert Dearden (1981/1984).

\footnotetext{
${ }^{1}$ http://www.exploreevolution.com/about the book.php.
} 
After, somewhat uncontroversially, rejecting logical positivism as a basis for curriculum design, Dearden points out that "what is 'controversial' may itself be a matter of controversy" (Dearden, 1981/1984: 85). He then goes on, as is well known, to propose an epistemic criterion of the controversial in which "a matter is controversial if contrary views can be held on it without those views being contrary to reason" (p. 86). He points out that several possible kinds of controversial issue may be distinguished: "cases where we simply have insufficient evidence to settle the matter, though in principle there is no reason why it should not be settled as more or better evidence becomes available" (ibid.); "where consideration-making criteria are agreed but the weight to be given them is not" (ibid.); "where there is no agreement even on the criteria as to what will count" (ibid.) and, finally, "where not just individual criteria but whole frameworks of understanding are different" (p. 87). This four-fold categorisation has been valuably extended with specific reference to the teaching of controversial issues in school science by Ralph Levinson (2006).

However, Dearden's epistemic criterion of the controversial is not the only one. Indeed, standard works on the teaching of controversial issues (e.g., Wellington, 1986; Claire \& Holden, 2007; Hess, 2009) provide broader, often fuzzier, definitions. Here, for instance, is one from the opening chapter of The Challenge of Teaching Controversial Issues:

In general terms a controversial issue is one in which

- the subject/area is of topical interest

- there are conflicting values and opinions

- there are conflicting priorities and material interests

- emotions may become strongly aroused

- the subject/area is complex.

(Claire \& Holden, 2007: 5-6)

There is, of course, a long tradition of writing in education on controversial issues and examining precisely what it is that makes an issue controversial (e.g., Stradling, 1984; Bridges, 1986; McLaughlin, 2003). Michael Hand (2008) has defended and extended Dearden's epistemic 
criterion. There is much in Hand's position that is attractive. He argues that "What distinguishes teaching-as-settled from teaching-as-controversial (or directive from nondirective teaching) is not a pedagogical method or style, but the willingness of the teacher to endorse one view on a matter as the right one" (Hand, 2008: 213) and points out that "The English word 'controversial' means simply 'disputed', and the existence of dispute is an unpromising criterion for what should be taught nondirectively" (p. 214). Hand then proceeds to critique curriculum materials, even guides, that take too broad a view of 'controversy'. For example, he points out topics such as bullying and racism are frequently described as controversial which hardly fits with standard advice given in such material and guides that teachers should teach controversial issues in a balanced manner, giving equal weight to opposing views.

And yet I am not entirely persuaded by Hand's arguments (Reiss, 2011). He relies on the premise that "that the central aim of education is to equip students with a capacity for, and inclination to, rational thought and action" (p. 218). This seems to me quite a narrow view. I cannot here review all the arguments as to the aims of education (cf. Marples, 1999) but Hand seems to privilege rationality. With John White, I prefer an emphasis on human flourishing (Reiss \& White, 2013). In any event, unless one is prepared to define 'controversy' at a particular moment in time and place in space and for a particular audience, it is clear that any attempt simply to divide issues into 'controversial' and 'non-controversial' is unlikely to succeed for all but the most mundane points of possible contention: there are degrees of controversy and, as Hand and many others acknowledge, what is controversial for one group may not be controversial for another. Indeed, creationism provides a useful illustration of this point as it is controversial neither for scientists nor for creationists - though for opposing reasons.

The scientific understanding of biodiversity is far from complete but the narrative is a powerful one. By 3.5 billion years ago, probably earlier, life had evolved on Earth. By the time of the earliest fossils, life was unicellular and bacteria-like. Over the next three and a half billion years, the workings of natural selection, possibly aided by other mechanisms (genetic drift, etc.), eventually resulted in the 10 million or so species, including our own, that we find today. 
The scientific worldview is materialistic in the sense that it is neither idealistic nor admits of non-physical explanations (here, 'physical' includes such things as energy and the curvature of space as well as matter). There is much that remains unknown about evolution. How did the earliest self-replicating molecules arise? What caused membranes to exist? How key were the earliest physical conditions - temperature, the occurrence of water and so forth? But the scientific presumption is that these questions will either be answered by science or remain unknown. Although some scientists might (sometimes grudgingly) admit that science cannot disprove supernatural explanations, scientists do not employ such explanations in their work (the tiny handful of seeming exceptions only attest to the strength of the general rule).

Whereas there is only one mainstream scientific understanding of biodiversity, there are a considerable number of religious ones. Many religious believers are perfectly comfortable with the scientific understanding, either on its own or accompanied by a belief that evolution in some sense takes place within God's holding, whether or not God is presumed to have intervened or acted providentially at certain key points (e.g., the origin of life or the evolution of humans). But many other religious believers adopt a more creationist perspective or that of intelligent design (Reiss, 2008a).

Most of the literature on creationism (and/or intelligent design) and evolutionary theory puts them in stark opposition. Evolution is consistently presented in creationist books and articles as illogical (e.g., natural selection cannot, on account of the second law of thermodynamics, create order out of disorder; mutations are always deleterious and so cannot lead to improvements), contradicted by the scientific evidence (e.g., the fossil record shows human footprints alongside animals supposed by evolutionists to be long extinct; the fossil record does not provide evidence for transitional forms), the product of non-scientific reasoning (e.g., the early history of life would require life to arise from inorganic matter $-\mathrm{a}$ form of spontaneous generation rejected by science in the $19^{\text {th }}$ Century; radioactive dating makes assumptions about the constancy of natural processes over aeons of time whereas we increasingly know of natural processes that affect the rate of radioactive decay), the product of those who ridicule the word of God, and a cause of a whole range of social evils (from eugenics, Marxism, Nazism and racism to juvenile delinquency) - e.g., Baker (2003), Parker (2006) and articles too many to mention in the journals 
and other publications of such organisations as Answers in Genesis, the Biblical Creation Society, the Creation Science Movement and the Institute for Creation Research.

By and large, creationism has received similarly short shrift from those who accept the theory of evolution. In a fairly early study, the philosopher of science Philip Kitcher argued that "in attacking the methods of evolutionary biology, Creationists are actually criticizing methods that are used throughout science" (Kitcher, 1983: 4-5). Kitcher concluded that the flat-earth theory, the chemistry of the four elements, and mediaeval astrology "have just as much claim to rival current scientific views as Creationism does to challenge evolutionary biology" (p. 5).

Many scientists have defended evolutionary biology from creationism (Selkirk \& Burrows, 1987; Good et al., 1992; Interacademy Panel on International Issues, 2006). The main points that are frequently made are that evolutionary biology is good science since not all science consists of controlled experiments where the results can be collected within a short period of time; that creationism (including 'scientific creationism') isn't really a science in that its ultimate authority is scriptural and theological rather than the evidence obtained from the natural world; and that an acceptance of evolution is fully compatible with a religious faith.

\section{Worldviews}

In World Views: From fragmentation to integration, Diederik Aerts et al. (1994) write: "A world view is a coherent collection of concepts and theorems that must allow us to construct a global image of the world, and in this way to understand as many elements of our experience as possible" (p. 17). Of course, this does not mean that a worldview is correct; indeed, alternate worldviews are not infrequently incommensurate. In science education the notion of worldviews (whether one word or two) is increasingly being employed. For example, in the edited volume Science, Worldviews and Education (Matthews, 2009), a number of philosophers, scientists and science educators use the thinking behind worldviews to explore a range of issues including whether science itself is a worldview and whether science can test supernatural worldviews. 
I aim to explicate the notion of 'worldviews' in the context of creationism and intelligent design by considering the film March of the Penguins (Reiss, 2009). March of the Penguins is a 2005 National Geographic feature film. It runs for approximately 85 minutes and has been an exceptional success. It won an Academy Award in 2006 for Best Documentary Feature and has been the most financially successful nature film in American motion picture history. The reasons for its success are no doubt several: the photography is phenomenal; the emperor penguin's story is extraordinary; the adults are elegant; the chicks are irredeemably cute as they look fluffy, feebly wave their little wings and learn to walk; the way in which the birds survive the Antarctic winter is awesome; the plaintive cries of mothers who lose their chicks in snow storms are heartrending. But one perhaps unexpected reason is that the film has been a great success among the Christian right.

For example, if one enters " "march of the penguins" Christian' into Google, at the time of writing (24 April 2017) one finds 187,000 hits. Third of these is a review of the film by Mari Helms (n.d.) on ChristianAnswers.Net, which describes itself as "a mega-site providing biblical answers to contemporary questions for all ages and nationalities with over 45-thousand files" (http://christiananswers.net/). After a fairly detailed summary of the subject matter of the film, the review goes on to discuss the lessons that the film has to teach about love, perseverance, the existence of God and friendship/commraderie (sic). An extended quotation from the review [underlinings indicate hyperlinks to other pages on the ChristianAnswers. Net website] illustrates the presuppositions of the author:

"March of the Penguins" has lessons to teach about:

"LOVE": According to the film, the penguins take this tremendous journey for "love" and to find a mate and reproduce. The dedication, cooperation, and affection are exemplary between the pair.

PERSEVERANCE: We could learn a lot about perseverance from Emperor penguins. I was quickly reminded of the ant in Proverbs 6:7-8 "It has no commander, overseer or ruler, yet it stores its provisions in summer and gathers its food at harvest." No one is reminding these penguins what to do; they know what to do, and they do it. They are prepared, persistent and committed, much like we are called to be as witnesses for Jesus 
Christ. 1 Peter 4:15 "Always be prepared to give an answer to everyone who asks you to give the reason for the hope that you have."

The penguins endure treacherous conditions, yet they continue on their journey, focusing on what lies ahead (new life). It may be a bit of a stretch, but I thought of what we, as Christians have to endure to get what lies ahead for us (eternal life). Philippians 3:14 "I press on toward the goal to win the prize for which God has called me heavenward in Christ Jesus."

THE EXISTENCE OF GOD: One year in the life of an Emperor penguin is a great indication of the existence and character of God. Romans 1:20 'For since the creation of the world God's invisible qualities - his eternal power and divine nature - have been clearly seen, being understood from what has been made, so that men are without excuse." He is absolutely perfect! Every detail has been taken into account, and every provision has been made. Witnessing all the love and care that He must have put into creating the penguins is small compared to what He put into creating us. Matthew 6:26 "Look at the birds of the air; they do not sow or reap or store away in barns, and yet your heavenly Father feeds them. Are you not much more valuable than they?" Leaving the theater, I was more in awe and in love with my $\underline{\text { Creator. }}$

(Helms, n.d.)

The reason for this long quotation is not to subject it to theological or scientific critique - which would be easy. Rather, the value of the quotation is that in the widely used four-fold framework of Ian Barbour (1990), who explores how science and religion can be understood to relate, it manifests an integrated relationship (as opposed to one of conflict, of independence or of dialogue). The worldview is one in which it is straightforward to read from penguin behaviour to human behaviour though it is worth noting that the argument is neither entirely anthropomorphic (where non-human behaviour is interpreted as if it was the behaviour of humans) nor one in which the natural world is seen as the source of instruction as to how humans should behave. Rather, it is scripture that has primacy; the natural world is held up not so much as a model for us to imitate but as an illustration of how the natural world can manifest that which God wishes for humanity. 
The 'worldviews' perspective on creationism is useful for two reasons: first it indicates the difficulty of using the criterion of 'reason' to decide whether an issue is controversial or not since, without embracing epistemological relativism, it highlights the importance of perspective in these matters - for many people, the position from which one can view dispassionately is so distant that one cannot from there see in much detail. Secondly, as I shall go on to argue, it suggests that standard ways of addressing the diversity of student views in a science classroom may be inadequate.

\section{Dealing with creationism and intelligent design in the secondary science classroom}

Few countries have produced explicit guidance as to how schools might deal with the issues of creationism or intelligent design in the science classroom. Indeed, the government production of such guidance raises issues about the extent to which it is appropriate for the state to propose or even enforce a common view on such issues as opposed to allowing decisions to be made at more local levels, whether by school boards, parents, teachers or others.

One country that has produced such guidance is England. In the summer of 2007, after months of behind-the-scenes meetings and discussions, the then DCSF (Department of Children, Schools and Families) Guidance on Creationism and Intelligent Design received Ministerial approval and was published (DCSF, 2007). The Guidance points out that the use of the word 'theory' in science (as in 'the theory of evolution') can mislead those not familiar with science as a subject discipline because it is different from the everyday meaning (i.e., of being little more than an idea). In science the word indicates that there is a substantial amount of supporting evidence, underpinned by principles and explanations accepted by the international scientific community. The Guidance goes on to state: 'Creationism and intelligent design are sometimes claimed to be scientific theories. This is not the case as they have no underpinning scientific principles, or explanations, and are not accepted by the science community as a whole' (DCSF, 2007). The Guidance then goes on to say: 
Creationism and intelligent design are not part of the science National Curriculum programmes of study and should not be taught as science. However, there is a real difference between teaching ' $\mathrm{x}$ ' and teaching about ' $\mathrm{x}$ '. Any questions about creationism and intelligent design which arise in science lessons, for example as a result of media coverage, could provide the opportunity to explain or explore why they are not considered to be scientific theories and, in the right context, why evolution is considered to be a scientific theory.

(DCSF, 2007)

This seems to me a key point and one that is independent of country, whether or not a country permits the teaching of religion (as in the UK) or does not (as in France, Turkey and the USA). Many scientists, and some science educators, fear that consideration of creationism or intelligent design in a science classroom legitimises them. For example, the excellent book Science, Evolution, and Creationism published by the US National Academy of Sciences and Institute of Medicine asserts "The ideas offered by intelligent design creationists are not the products of scientific reasoning. Discussing these ideas in science classes would not be appropriate given their lack of scientific support" (National Academy of Sciences and Institute of Medicine, 2008: $52)$.

As I have argued (Reiss, 2008b), I agree with the first sentence of this quotation but disagree with the second. Just because something lacks scientific support doesn't seem to me a sufficient reason to omit it from a science lesson. When I was taught physics at school, and taught it extremely well in my view, what I remember finding so impressive was that we could discuss almost anything providing we were prepared to defend our thinking in a way that admitted objective evidence and reasoned argument. Nancy Brickhouse and Will Letts (1998) have argued that one of the central problems in science education is that science is often taught 'dogmatically'. With particular reference to creationism they write:

Should student beliefs about creationism be addressed in the science curriculum? Is the dictum stated in the California's Science Frameworks (California Department of Education, 1990) that any student who brings up the matter of creationism is to be 
referred to a family member of member of the clergy a reasonable policy? We think not. Although we do not believe that what people call 'creationist science' is good science (nor do scientists), to place a gag order on teachers about the subject entirely seems counterproductive. Particularly in parts of the country where there are significant numbers of conservative religious people, ignoring students' views about creationism because they do not quality as good science is insensitive at best.

(Brickhouse \& Letts, 1998: 227)

More recently, Thomas Nagel (2008) has argued that so-called scientific reasons for excluding intelligent design (ID) from science lessons do not stand up to critical scrutiny (cf. Koperski, 2008). With reference to the USA he concludes:

I understand the attitude that ID is just the latest manifestation of the fundamentalist threat, and that you have to stand and fight them here or you will end up having to fight for the right to teach evolution at all. However, I believe that both intellectually and constitutionally the line does not have to be drawn at this point, and that a noncommittal discussion of some of the issues would be preferable.

(Nagel, 2008: 205)

\section{Dealing with creationism and intelligent design elsewhere in the curriculum}

Of course, science lessons are not the only place where teaching about creationism and intelligent design might take place in the curriculum. One might also expect them to be addressed in religious education (RE) lessons, for countries that have such lessons. In England, the DCSF and QCA (Qualifications and Curriculum Authority) published a non-statutory national framework for RE and associated teaching units that include a unit asking 'How can we answer questions about creation and origins?' (QCA, 2006). The unit focuses on creation and the origins of the universe and human life, as well as the relationships between religion and science. A carefully written 23-page guide was produced. Along with its non-evaluative stance towards the various positions, what strikes me as a science educator is the high expectations of students it 
has. For example, in answer to the question 'Is the universe designed? Who could have designed it?', it is suggested that teachers of 13-14-year-olds should:

Give the pupils opportunities to explore, through a website, DVD or written text (see 'Resources'), a range of different answers to these questions, including answers given by members of different faiths. These answers should include the views of creationists, evolutionists, advocates of intelligent design and philosophers of religion, such as Anselm, Thomas Aquinas, Blaise Pascal and Francis Bacon.

(QCA, 2006: 16)

We can note that this non-evaluative stance towards the various positions has taken place in a context where, since the late 1950s in England and Wales, advocates of religious education in schools have abandoned a form of religious education where the inculcation of Christianity was a central aim and in which Christianity was often presumed to be the sole framework within which life found meaning and moral direction. Nowadays a more pluralist vision is preferred (e.g., Jackson, 2004) in which students are enabled to develop, clarify and refine their own views about matters religious. This is very different to the position in science where the presumption, whether implicit or stated, is nearly always that the scientific understanding of the world is either a valid one or the valid one.

Finally, I should note that the distinction between science lessons and religious education lessons, while it may hold at secondary level with subject-specific teaching rather breaks down at primary level where a pupil generally has the same teacher for most or all lessons. From an epistemological point of view this is both the strength and potential weakness of primary teaching. Teaching in the primary school has the potential to make links between subjects with greater ease than is generally the case at secondary school, precisely because the one teacher is responsible for such a diversity of subjects. At the same time, a primary teacher is unlikely to know each subject in as much depth as a secondary specialist and therefore there is a greater likelihood that subject-specific differences may be elided. This suggests that it may be particularly important for primary teachers to be explicit as to whether they are helping their pupils to understand an issue from the perspective of science, of history, of religion or whatever. 


\section{Discussion}

Whatever the subject matter and age range of a class, and the country in which a teacher is teaching, there is much to be said for a teacher bearing in mind that for some students, evolution, creationism and intelligent design are likely to be sensitive issues. Rather less has been written in the philosophy of education literature about sensitive issues than about controversial ones. Death, sexuality, drugs policy and animal experimentation are examples of issues that are sensitive for many students and many teachers are used to dealing respectfully with students when dealing with sensitive issues.

An advantage of shifting the discourse from controversy to sensitivity is that one shifts the focus from epistemology to pedagogy. One can be sensitive with someone in respect of an issue without implying that one shares the same perspective (or worldview) as the person to whom one is being respectful and considerate; different notions of respect are discussed by Rosenblith and Bindewald (2014) who "make a case for an approach to civic education in the public schools that is rooted in engagement" (p. 596). Explicitly accepting the teaching of evolution as controversial is difficult for many science teachers as the distinction between this and evolution as controversial is a fine one and many science teachers are likely to see it as selling out to creationists (cf. Hermann, 2008).

Of course, my suggestion that teaching in this field be considered akin to the teaching of traditional sensitive issues does not absolve teachers and relevant others such as curriculum designers and textbook authors (Williams, 2008), whatever their specialisms, from having as good a knowledge of the issues as they can. Mary Midgley (2007) points out that there is much to be said in initial teacher education for bringing "together lecturers in science and in religious studies in pairs - of course after adequate training - and let them jointly teach classes that combine both sets of trainee teachers together" (p. 42). In my experience such joint teaching, though expensive and sometimes difficult to organise, can work well, so long as there is sufficient mutual trust between the lecturers. 
In a school science lesson when teaching evolution there is much therefore to be said for allowing students to raise any doubts they have and doing one's best in such circumstances to have a genuine scientific discussion about the issues raised. The word 'genuine' does not mean that creationism or intelligent design deserve equal time with evolution, nor does it mean that a science teacher should present creationism or intelligent design as valid alternative to the theory of evolution. It is perfectly appropriate for a science teacher to critique arguments for creationism or intelligent design that purport to be scientific. However, in certain classes, depending on the comfort of the teacher in dealing with such issues and the make up of the student body, it can be appropriate to deal with these issues. If questions about the validity of evolution or issues about creationism and intelligent design arise during science lessons they can be used to illustrate a number of aspects of how science works and how scientific knowledge is built up over time, while always being open to the possibility of refutation and change.

Having said that, teaching about evolution, creationism or intelligent design, in whatever lesson, is often not straightforward. Some students get very heated; others remain silent even if they disagree profoundly with what is said. We need to seriously and respectfully the concerns of students who do not accept the theory of evolution while still introducing them to it. There is much to be said for aiming to get students to understand rather than necessarily to believe or accept the theory of evolution (Smith \& Siegel, 2004; Reiss, 2008b). While it is unlikely that even respectful teaching will help students who have a conflict between science and their religious beliefs to resolve the conflict, good science teaching can help students to manage it and to learn more science (cf. Long, 2011).

Creationism can profitably be seen not as a simple misconception that careful science teaching can correct, as careful science teaching might hope to persuade a student that an object continues at uniform velocity unless acted on by a net force, or that most of the mass of a plant comes from air. Rather, a student who believes in creationism can be seen as inhabiting a non-scientific worldview, that is a very different way of seeing the world. 


\section{References}

Aerts, D., Apostel, L., De Moor, B., Hellemans, S. Maex, E., Van Belle, H. \& Van der Veken, J. (1994). World views: From fragmentation to integration. Brussels: VUB Press. Available at http://www.vub.ac.be/CLEA/pub/books/worldviews.pdf.

Baker, S. (2003). Bone of contention: Is evolution true?, $3^{\text {rd }}$ edn. Rugby: Biblical Creation Society.

Barbour, I. G. (1990). Religion in an age of science: The Gifford Lectures 1989-1991, volume 1. London: SCM.

Behe, M. J. (1996). Darwin's black box: The biochemical challenge to evolution. New York: Free Press.

Bennett, T. (2004). Pasts beyond memory: Evolution, museums, colonialism. London: Routledge.

Blancke, S., Hjermitslev, H. H. \& Kjærgaard, P. C. (Eds.) (2014). Creationism in Europe. Baltimore: John Hopkins University Press.

Brickhouse, N. W. \& Letts, IV, W. J. (1998). The problem of dogmatism in science education. In J. T. Sears \& J. C. Carper (Eds.), Curriculum, religion, and public education: Conversations for an enlarging public square (pp. 221-230). New York: Teachers College, Columbia University.

Bridges, D. (1986). Dealing with controversy in the curriculum: a philosophical perspective. In J. J. Wellington (Ed.) Controversial issues in the curriculum (pp. 19-38). Oxford: Basil Blackwell.

California Department of Education (1990). Science framework for California public schools. Sacramento: California Department of Education.

Claire, H. \& Holden, C. (Eds.) (2007). The challenge of teaching controversial issues. Stoke-onTrent: Trentham.

DCSF (2007). Guidance on creationism and intelligent design. Available at www.teachernet.gov.uk/docbank/index.cfm?id=11890.

Dearden, R. F. (1984). Theory and practice in education. London: Routledge \& Kegan Paul.

Dembski, W. A. (1998). The design inference: Eliminating chance through small probabilities. Cambridge, Cambridge University Press. 
Good, R. G., Trowbridge, J. E., Demastes, S. S., Wandersee, J. H., Hafner, M. S. \& Cummins, C. L. (Eds) (1992). Proceedings of the 1992 evolution education research conference. Baton Rouge: Louisiana State University.

Graebsch, A. \& Schiermeier, Q. (2006). Anti-evolutionists raise their profile in Europe. Nature, 444, 406-407.

Hand, M. (2008). What should we teach as controversial? A defense of the epistemic criterion. Educational Theory, 58, 213-228.

Helms, M, (n.d.). Movie review: March of the Penguins http://www.christiananswers.net/spotlight/movies/2005/marchofthepenguins2005.html.

Hermann, R. S. (2008). Evolution as a controversial issue: a review of instructional approaches. Science \& Education, 17, 1011-1032.

Hess, D. E. (2009). Controversy in the classroom: The democratic power of discussion. New York: Routledge.

Interacademy Panel on International Issues (2006). IAP statement on the teaching of Evolution. Available at http://www.interacademies.net/File.aspx?id=6150.

Jackson, R. (2004). Rethinking religious education and plurality: Issues in diversity and pedagogy. Abingdon: Routledge.

Johnson, P. E. (1999). The wedge: breaking the modernist monopoly on science. Touchstone, 12(4), 18-24.

Jones, L. \& Reiss, M. J. (Eds.) (2007). Teaching about Scientific origins: Taking account of creationism. New York: Peter Lang.

Kitcher, P. (1983). Abusing science: The case against creationism. Milton Keynes: Open University Press.

Koperski, J. (2008). Two bad ways to attack intelligent design and two good ones, Zygon, 43, 433-449.

Laats, A. \& Siegel, H. (2016). Teaching evolution in a creation nation. Chicago: University of Chicago Press.

Levinson, R. (2006). Towards a theoretical framework for teaching controversial socio-scientific issues. International Journal of Science Education, 28, 1201-1224.

Long, D. (2011). Evolution and religion in American education: An ethnography. Dordrecht: Springer. 
McLaughlin, T. (2003). Teaching controversial issues in citizenship education. In A. Lockyer, B. Crick \& J. Annette (Eds.) Education for democratic citizenship: Issues of theory and practice (pp. 149-160). Avebury: Aldershot.

Marples, R. (Ed.) (1999). The aims of education. London: Routledge.

Matthews, M. (Ed.) (2009). Science, worldviews and education: Reprinted from the journal Science \& Education. Dordrecht: Springer.

Meyer, S. C., Nelson, P. A., Moneymaker, J., Minnich, S. \& Seelke, R. (2009). Explore evolution: The arguments for and against neo-Darwinism. Melbourne: Hill House.

Midgley, M. (2007). Impact no. 15: Intelligent design theory and other ideological problems. London: Philosophy of Education Society of Great Britain.

Miller, J. D., Scott, E. C. \& Okamoto, S. (2006). Public acceptance of evolution. Science, 313, 765-766.

Moore, R. (2007). The history of the creationism/evolution controversy and likely future developments. In L. Jones \& M. Reiss (Eds.) Teaching about scientific origins: Taking account of creationism (pp. 11-29). New York: Peter Lang.

Nagel. T. (2008). Public education and intelligent design. Philosophy \& Public Affairs, 36, 187205.

National Academy of Sciences and Institute of Medicine (2008). Science, evolution, and creationism. Washington, DC: National Academies Press.

Parker, G. E. (2006). Creation: Facts of life - how real science reveals the hand of God. Los Angeles, CA: New Leaf Press.

QCA (2006). How can we answer questions about creation and origins? Learning from religion and science: Christianity, Hinduism, Islam and Humanism - Year 9 http://www.qcda.gov.uk/libraryAssets/media/qca-06-2728_y9_science_religion_master.pdf.

Reiss, M. J. (2008a). Should science educators deal with the science/religion issue? Studies in Science Education, 44, 157-186.

Reiss, M. J. (2008b). Teaching evolution in a creationist environment: an approach based on worldviews, not misconceptions. School Science Review, 90(331), 49-56.

Reiss, M. J. (2009). Imagining the world: the significance of religious worldviews for science education. Science \& Education, 18, 783-796. 
Reiss, M. J. \& White, J. (2013) An aims-based curriculum: The Significance of human flourishing for schools. London: IOE Press.

Rosenblith, S. \& Bindewald, B. (2014). Between mere tolerance and robust respect: mutuality as a basis for civic education in pluralist democracies. Educational Theory, 64, 589-606.

Scott, M. (2007). Rethinking evolution in the museum. Abingdon: Routledge.

Selkirk, D. R. \& Burows, F. J. (Eds.) (1987). Confronting creationism: Defending Darwin. Kensington, NSW: New South Wales University Press.

Smith, M. U. \& Siegel, H. (2004). Knowing, believing, and understanding: what goals for science education? Science \& Education, 13, 553-582.

Stradling, R. (1984). Controversial issues in the classroom. In R. Stradling, M. Noctor \& B. Baines (Eds.) Teaching controversial issues (pp. 1-12). London: Edward Arnold.

Trollinger, S. L. \& Trollinger, W. V. (2016). Righting America at the Creation Museum. Baltimore: Johns Hopkins Press.

Wellington, J. (Ed.) (1986). Controversial issues in the curriculum. Oxford: Basil Blackwell.

Williams, J. D. (2008). Creationist teaching in school science: A UK perspective. Evolution: Education and Outreach, 1, 87-95. 